\title{
Efficient Discrimination of Race Mutants of Xanthomonas campestris pv. oryzae by RFLP Analysis Using Plasmid pJEL101 Containing a Highly Repetitive DNA Element
}

\author{
Mitsuo HoriTA*, Kenichi TsuchiYA****, Hisatoshi KAKU*, \\ Kazuyuki HiRAYAE* and Tadaaki HIBI*,**
}

Key words : Xanthomonas campestris pv. oryzae, race mutant, RFLP analysis.

Xanthomonas campestris pv. oryzae (XCO) is a causal agent of bacterial leaf blight of rice. So far XCO has been divided into 7 to 9 races in Japan $^{9)}$ and 6 races in the Philippines ${ }^{7}$, based on the pathogenicity to differential rice cultivars. When genomic DNA of XCO was probed with pJEL101, a pUC18 plasmid containing a 2.4 kb EcoRI-HindIII fragment with one highly repetitive DNA sequence derived from XCO, restriction fragment length polymorphism (RFLP) analysis was efficient to differentiate strains of races from $\mathrm{Japan}^{3)}$ and the Philippines $^{4)}$. In the present study, we compared RFLP patterns of various XCO pathogenicity mutants induced by $N$-methyl- $N^{\prime}$-nitro- $N$-nitrosoguanidine (NTG) treatment with those of wild type strains, using 4 kinds of restriction enzymes (EcoRI, HindIII, EcoRV and ClaI) and pJEL101 as a probe.

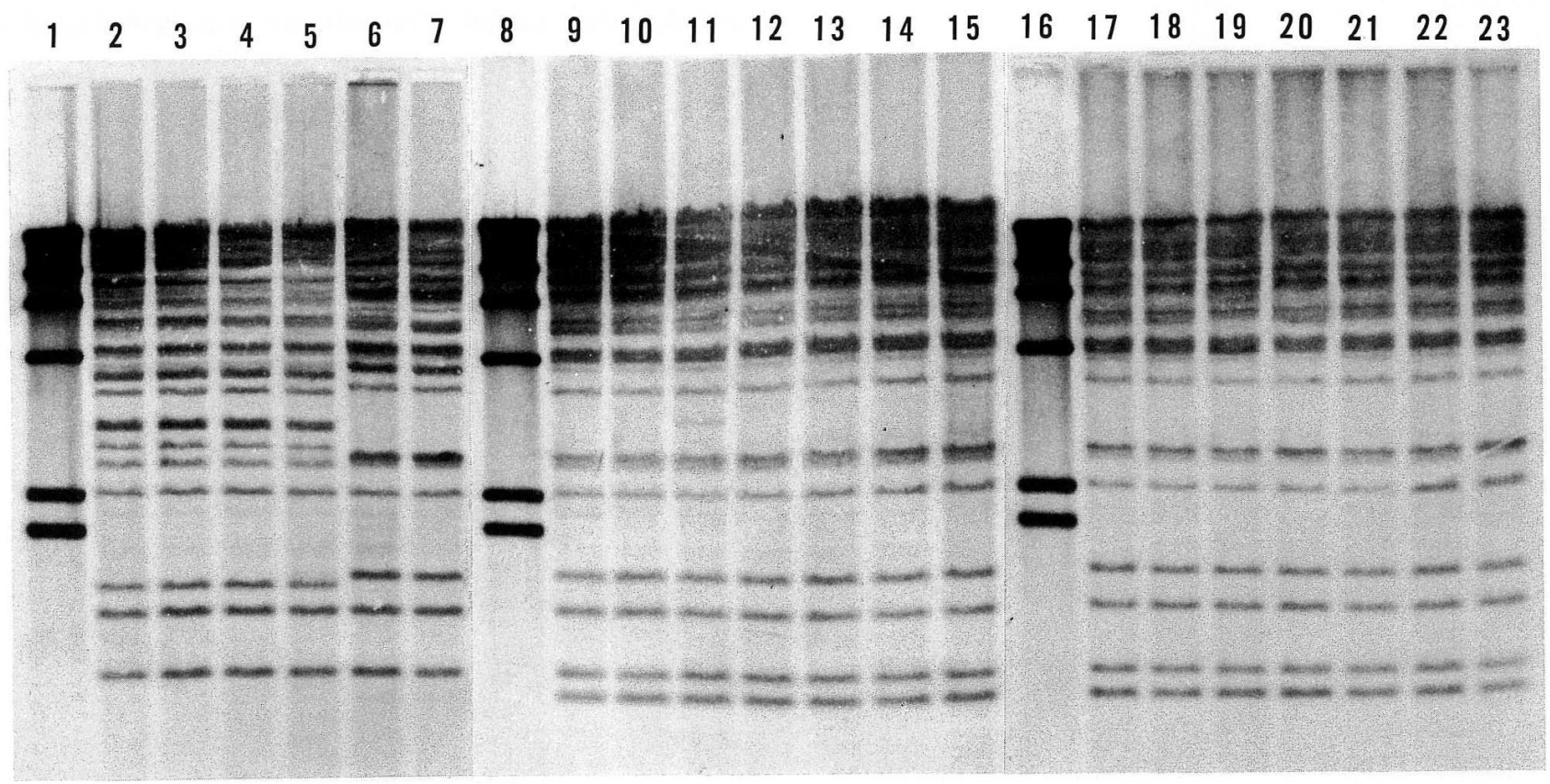

Fig. 1. Southern blot analysis of total DNA from strains of Xanthomonas campestris pv. oryzae wild types and pathogenicity mutants. The probe was photobiotin-labeled pJEL101. Lanes 1, 8 and 16, $\lambda$ DNA digested by HindIII; lane 2, wild type, race 1, PXO61; lane 3, race 1, PXO61PT; lane 4, PXO61NT3; lane 5, PXO61NT3RV1; lane 6, race $1 \rightarrow 2$, PXO61NT3RV2; lane 7, race $1 \rightarrow 2$, PXO61NT3RV3; lane 9, wild type, race 2, PXO63-6; lane 10, race 2, PXO63-6PT1; lane 11, race 2, PXO63-6PT2; lane 12, PXO63-6NT2; lane 13, PXO63-6NT3; lane 14, PXO63-6NT5; lane 15, PXO63-6NT8; lane 17, PXO63-6NT8I-1; lane 18, PXO63-6NT8I2; lane 19, PXO63-6NT8Lh; lane 20, PXO63-6NT11; lane 21, PXO63-6NT12; lane 22, PXO63-6NT15 and lane 23, PXO63-6NT17. DNA samples were digested with EcoRI before electrophoresis and transfer.

\footnotetext{
* National Institute of Agrobiological Resources, Tsukuba 305, Japan 農業生物資源研究所

** Present address : Faculty of Agriculture, The University of Tokyo, Bunkyo-ku, Tokyo 113, Japan 学部

*** Corresponding author
} 
Bacterial strains. The wild type strains used in this study were obtained from the International Rice Research Institute (IRRI). Pathogenicity mutants listed in Table 1 were derived from Tsuchiya et $a l^{10)}$ All strains have been verified by extensive screening with pathogenicity tests to fully-grown rice plants ${ }^{10,11)}$.

Preparation of bacterial DNA. Bacteria were streaked on peptone sucrose agar plates (PSA: peptone $10 \mathrm{~g}$, sucrose $10 \mathrm{~g}$, sodium glutamate $1 \mathrm{~g}$, agar $15 \mathrm{~g}$, distilled water $1000 \mathrm{ml}, \mathrm{pH} 7.0)^{10)}$ and kept at $28^{\circ} \mathrm{C}$ for 48

Table 1. Wild type strains and pathogenicity mutants of Xanthomonas campestris pv. oryzae used in RFLP analyses

\begin{tabular}{|c|c|c|}
\hline Strain & Race & Characteristics $^{\mathrm{a})}$ \\
\hline \multicolumn{3}{|c|}{ Wild type (Philippine isolate) } \\
\hline PXO61 & 1 & $\left.\mathrm{SM}^{\mathrm{s}} \mathrm{b}\right)$ \\
\hline $\mathrm{PXO} 23$ & 1 & $\mathrm{SM}^{\mathrm{s}}$ \\
\hline PXO63-6 & 2 & $\mathrm{SM}^{\mathrm{s}}$ \\
\hline PXO86 & 2 & $\mathrm{SM}^{\mathrm{s}}$ \\
\hline PXO138 & 2 & $\mathrm{SM}^{\mathrm{s}}$ \\
\hline PXO158 & 2 & $\mathrm{SM}^{\mathrm{s}}$ \\
\hline PXO159 & 2 & $\mathrm{SM}^{\mathrm{s}}$ \\
\hline PXO171 & 2 & $\mathrm{SM}^{\mathrm{s}}$ \\
\hline PXO172 & 2 & $\mathrm{SM}^{\mathrm{s}}$ \\
\hline PXO175 & 2 & $\mathrm{SM}^{\mathrm{s}}$ \\
\hline PXO22 & 3 & $\mathrm{SM}^{\mathrm{s}}$ \\
\hline PXO71 & 4 & $\mathrm{SM}^{\mathrm{s}}$ \\
\hline PXO80 & 5 & $\mathrm{SM}^{\mathrm{s}}$ \\
\hline \multicolumn{3}{|l|}{ Mutant } \\
\hline PXO61PT & 1 & $\mathrm{SM}^{\mathrm{r}}$, parent strain \\
\hline PXO61NT3 & - & $\mathrm{SM}^{\mathrm{r}}$, avirulent, non-pigmented \\
\hline PXO61NT3RV1 & - & $\begin{array}{l}\mathrm{SM}^{\mathrm{r}} \text {, avirulent, revertant for } \\
\text { pigmentation }\end{array}$ \\
\hline PXO61NT3RV2 & $1 \rightarrow 2$ & $\begin{array}{l}\mathrm{SM}^{\mathrm{r}} \text {, reverted from PXO61NT3, } \\
\text { race mutant }\end{array}$ \\
\hline PXO61NT3RV3 & $1 \rightarrow 2$ & $\begin{array}{l}\mathrm{SM}^{\mathrm{r}} \text {, reverted from PXO61NT3, } \\
\text { race mutant }\end{array}$ \\
\hline PXO63-6PT1 & 2 & $\mathrm{SM}^{\mathrm{r}}$, parent strain 1 \\
\hline PX063-6PT2 & 2 & $\mathrm{SM}^{\mathrm{r}}$, parent strain 2 \\
\hline PXO63-6NT2 & 2 & $\begin{array}{l}\mathrm{SM}^{r} \text {, non-pigmented, resistant to } \\
\mathrm{OP}_{2} \text { phage }\end{array}$ \\
\hline PXO63-6NT3 & 2 & $\mathrm{SM}^{\mathrm{r}}$, resistant to $\mathrm{OP}_{2}$ phage \\
\hline PXO63-6NT5 & - & $\mathrm{SM}^{\mathrm{r}}$, weakly virulent \\
\hline PXO63-6NT8 & 2 & $\mathrm{SM}^{\mathrm{r}}$, non-pigmented \\
\hline PXO63-6NT8I-1 & 2 & $\begin{array}{l}\mathrm{SM}^{\mathrm{r}} \text {, reisolated from inoculated } \\
\text { plant }\end{array}$ \\
\hline PXO63-6NT8I-2 & 2 & $\begin{array}{l}\mathrm{SM}^{\mathrm{r}} \text {, reisolated from inoculated } \\
\text { plant }\end{array}$ \\
\hline PXO63-6NT8Lh & 2 & $\begin{array}{l}\mathrm{SM}^{\mathrm{r}} \text {, non-pigmented, colony type } \\
\text { variant }^{c)}\end{array}$ \\
\hline PXO63-6NT11 & 2 & $\mathrm{SM}^{\mathrm{r}}$, non-pigmented \\
\hline PXO63-6NT12 & 2 & $\mathrm{SM}^{\mathrm{r}}$, non-pigmented \\
\hline PXO63-6NT15 & - & $\mathrm{SM}^{\mathrm{r}}$, weakly virulent \\
\hline PXO63-6NT17 & - & $\mathrm{SM}^{\mathrm{r}}$, weakly virulent \\
\hline
\end{tabular}

a) Details were described in Refs. 10) and 11).

b) $\mathrm{SM}^{\mathrm{s}}$ : streptomycin susceptible, $\mathrm{SM}^{\mathrm{r}}$ : streptomycin resistant.

c) See Refs 2) and 11). hr. From these plates, single colonies were picked and cultured on PSA slants. Then the bacteria were grown in $10 \mathrm{ml}$ of PS broth on a reciprocal shaker $(120 \mathrm{rpm})$ at $28^{\circ} \mathrm{C}$ for $24 \mathrm{hr}$. Genomic DNA was extracted by a modification of the procedure of Wilson ${ }^{12)}$. Bacterial cells were pelleted by centrifugation at $5000 \times g$ for 10 min and washed with STE buffer $(100 \mathrm{mM} \mathrm{NaCl}, 10 \mathrm{mM}$ Tris-HCl, $1 \mathrm{mM} \mathrm{Na}{ }_{2}$ EDTA, pH 8.0). The washed bacteria were resuspended with a mixture of $2.8 \mathrm{ml}$ of TE buffer (10 mM Tris-HCl, 1 mM Na ${ }_{2}$ EDTA, pH 8.0), 150 $\mu 1$ of $10 \%$ sodium dodecyl sulfate (SDS), $30 \mu 1$ of proteinase $\mathrm{K}(10 \mathrm{mg} / \mathrm{ml})$ and incubated at $37^{\circ} \mathrm{C}$ for $2 \mathrm{hr}$. Then $5 \mathrm{M} \mathrm{NaCl}$ solution was added to adjust the final concentration to $0.7 \mathrm{M}$ and $400 \mu 1$ of hexadecyltrimethylammonium bromide (CTAB) solution in $0.7 \mathrm{M} \mathrm{NaCl}$ was added. After incubation at $65^{\circ} \mathrm{C}$ for $15 \mathrm{~min}$, an equal volume of chloroform was mixed. The mixture was centrifuged at $6000 \times g$ for $10 \mathrm{~min}$. After the upper layer was transferred to a fresh tube, the DNA was precipitated by adding two volumes of ethanol and kept at $4^{\circ} \mathrm{C}$ for $10 \mathrm{~min}$. The DNA was collected by centrifugation at $6000 \times \mathrm{g}$ for $10 \mathrm{~min}$ at $4^{\circ} \mathrm{C}$, dried under vacuum and suspended in $\mathrm{TE}$ buffer. $\mathrm{CsCl}(2.1 \mathrm{~g})$ was added to the DNA solution $(2 \mathrm{ml})$ and completely dissolved. One hundred $\mu 1$ of ethidium bromide (EtBr) solution $(10 \mathrm{mg}$ / $\mathrm{ml}$ ) was then added. The mixture was centrifuged at

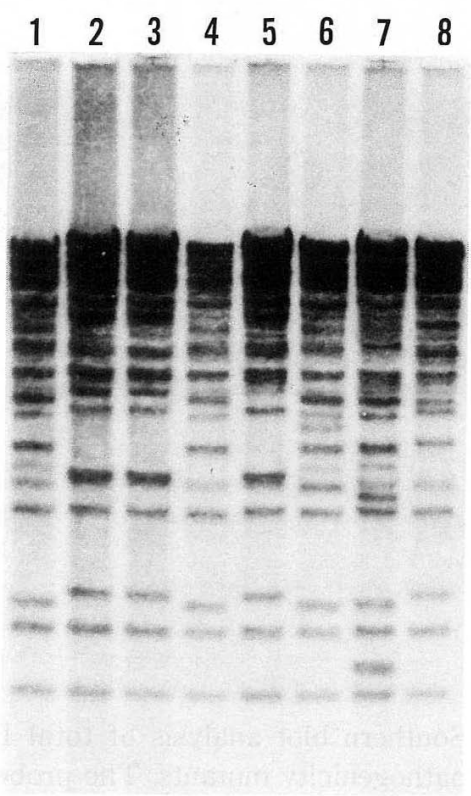

Fig. 2. Southern blot analysis of total DNA from strains of Xanthomonas campestris pv. oryzae race mutants and representing 5 different races. The probe was photobiotin-labeled pJEL101. Lane 1, race 1, PXO61; lane 2, race $1 \rightarrow 2$, PXO61NT3RV2; lane 3 , race $1 \rightarrow 2$, PXO61NT3RV3; lane 4, race 1, PXO23; lane 5, race 2, PXO86; lane 6, race 3 , PXO22; lane 7 , race 4, PXO71 and lane 8, race 5, PXO80. DNA samples were digested with EcoRI before electrophoresis and transfer. 
$70,000 \mathrm{rpm}$ in the Hitachi RP100 AT4 rotor for $24 \mathrm{hr}$ at $20^{\circ} \mathrm{C}$. The DNA band was collected by side puncture of the tube with a 18-gauge needle. An equal volume of $n$-butanol was added to the DNA solution and the elimination of $\mathrm{EtBr}$ was repeated several times. After the final elimination, the DNA was subsequently precipitated by adding two volumes of ethanol, collected by centrifugation at $6000 \times \mathrm{g}$ for $10 \mathrm{~min}$ at $4^{\circ} \mathrm{C}$, dried under vacuum and suspended in TE buffer.

Agarose gel electrophoresis. Approximately 1 $\mu \mathrm{g}$ of DNA was digested to completion with restriction enzymes (Eco RI, HindIII, EcoRV or ClaI, TOYOBO, 2$10 \mathrm{unit} / \mu \mathrm{g}$ DNA). Digested DNA samples ( $1 \mu \mathrm{g} / \mathrm{well}$ ) were run in $0.8 \%$ agarose gel immersed in TBE buffer (89 mM Tris, $89 \mathrm{mM}$ boric acid, $2.5 \mathrm{mM} \mathrm{Na}{ }_{2}$ EDTA) with electrophoresis at $50 \mathrm{~V}$ for $4 \mathrm{hr}$. Restriction fragment sizes were estimated by comparison to $\lambda$ DNA digested with HindIII.

DNA probe. The DNA probe pJEL101 used in this study was derived from a genomic library of $\mathrm{XCO}$ PXO86 and constructed into the cloning vector $\mathrm{pUC18}{ }^{5)}$. Labeling of pJEL101 by photobiotin was done as de scribed by McInnes et al. ${ }^{6}$ )

Southern hybridization. Transfer of DNA fragments from agarose gel onto nylon membrane (Hybond$\mathrm{N}$ ) was done according to instructions of the manufacture (Amersham Japan Co.). The blot was prehybridized

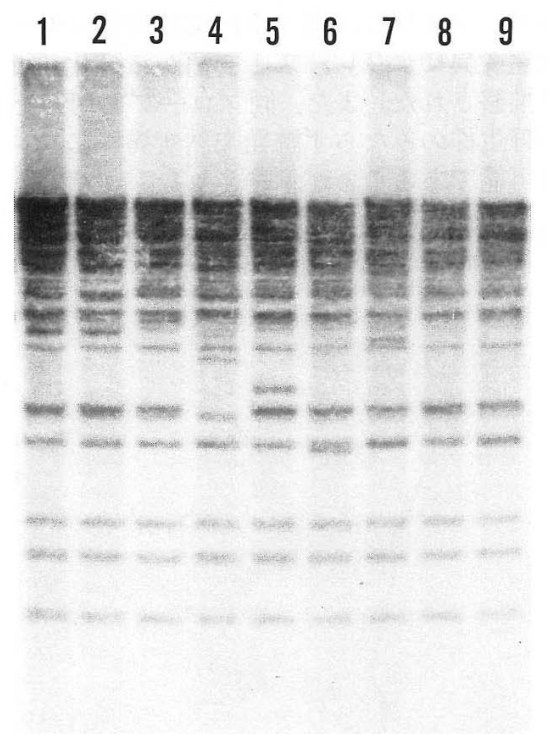

Fig. 3. Southern blot analysis of total DNA from race mutants and the race 2 strains of Xanthomonas campestris pv. oryzae. The probe was photobiotin-labeled pJEL101. Lane 1 , race $1 \rightarrow 2$, PXO61NT3RV2; lane 2, race $1 \rightarrow 2$, PXO61NT3RV3; lane 3, race 2, PXO86; lane 4, race 2, PXO138; lane 5, race 2, PXO158; lane 6, race 2, PXO159; lane 7, race 2, PXO171; lane 8, race 2, PXO172 and lane 9, race 2, PXO175. DNA samples were digested with EcoRI before electrophoresis and transfer. at $42^{\circ} \mathrm{C}$ for $2 \mathrm{hr}$ in a solution composed of $0.5 \%$ SDS, $5 \times$ Denhardt $(100 \times$ Denhardt contains $2 \%$ bovine serum albumin, 2\% Ficoll 400 and 2\% polyvinylpyrrolidone), $2 \times \mathrm{SSC}\left(20 \times \mathrm{SSC}\right.$ contains $3 \mathrm{M} \mathrm{NaCl}$ and $0.3 \mathrm{M} \mathrm{Na}_{3}$ citrate), $50 \%$ formamide and $20 \mu \mathrm{g} / \mathrm{ml}$ of denatured salmon sperm DNA. For hybridization, denatured labeled probe DNA $(40 \mathrm{ng} / \mathrm{ml})$ was added directly to the prehybridization solution, and the blot was incubated at $42^{\circ} \mathrm{C}$ for $24 \mathrm{hr}$. After hybridization, the blot was washed three times ( $5 \mathrm{~min}$ each) at room temperature in $2 \times \mathrm{SSC}$ containing $0.1 \%$ SDS and then two times (15 min each) at $55^{\circ} \mathrm{C}$ in $0.1 \times \mathrm{SSC}$ containing $0.1 \% \mathrm{SDS}$. Detection of DNA band was done as described by McInnes et al. ${ }^{6}$ )

When various mutant strains within the same race were compared, such as avirulent, weakly virulent and non-pigmented ones derived from PXO61 (race 1) or from PXO63-6 (race 2), their RFLP patterns were almost the same as those of their respective parent strains. On the other hand, RFLP patterns of two race mutants (race $1 \rightarrow 2$ ), PXO61NT3RV2 and PXO61NT3RV3, were significantly different from that of the parent strain (PXO61, race 1) (Fig. 1). RFLP patterns of these two race mutants were similar to that of race 2 strain PXO86, but differed from RFLP patterns of other races (strains $\mathrm{PXO} 23$, race $1 ; \mathrm{PXO} 22$, race $3 ; \mathrm{PXO} 71$, race 4 and PXO80, race 5) (Fig. 2). Furthermore, the RFLP patterns of the race mutants were almost identical to those of many other isolates belonging to race 2 (Fig. 3). The other enzymes used, HindIII, Eco RV and ClaI, also generated similar restriction patterns as EcoRI to discriminate between strains (data not shown).

From these results, RFLP analysis of XCO probed with pJEL101 could be an efficient tool for distinguishing races of wild type strains as well as those induced by mutagenesis. This would avoid the laborious inoculation tests to many rice plants.

Results also suggest that the race 2 strains in the Philippines might contain mutants derived from race 1 strains. Similar race mutants (race $2 \rightarrow 3$ ) induced by NTG mutagenesis have been reported earlier ${ }^{1)}$. Clear changes in RFLP patterns have been shown with race 1 $>2$ mutants. It is difficult to explain this phenomenon only by single point mutations or frame shifts. Nelson et al. ${ }^{8)}$ reported that $\mathrm{XCO}$ have several transposable elements such as TNX1, TNX6, TNX7 and TNX8, in which an element TNX8 hybridized with the repetitive element present in pJEL101 and had been designated IS1112. It is, therefore, possible that NTG mutagenesis induced homologous recombination and/or transposition in connection with IS1112 and arose changes in race specificity. Further research on this is now in progress.

We are grateful to Dr. J.E. Leach, Kansas State University, USA, for supplying DNA probe pJEL101. The authors also thank Dr. Ilkka Havukkala, STAFF-Institute (Society for Techno-Innovation of Agriculture, Forestry and Fisheries), for critical reading and correcting English. 


\section{Literature cited}

1. Ardales, E., Chua, N., Leach, J.E. and Leung, H. (1988). Isolation of chemically-induced mutants of Xanthomonas campestris pv. oryzae with changed race-specificity. Fifth International Congress on Plant Pathology, Kyoto, Japan, p. 103 (Abstr.).

2. Choi, J.E., Matsuyama, N. and Wakimoto, S. (1981). Colony type variants of Xanthomonas campestris pv. oryzae and their serological properties. Ann. Phytopathol. Soc. Jpn. 47 : 244-251.

3. Kaku, H., Noda, T., Hirayae, K., Matsumoto, S., Tsuchiya, K., Horita, M. and Hibi, T. (1992). RFLP analysis of races and mutants of Xanthomonas campestris pv. oryzae (2) Differentiation of Japanese races with the DNA probe pJEL101. Ann. Phytopathol. Soc. Jpn. 58: 592 (Abstr. in Japanese).

4. Leach, J.E., Rhodas, M.L., Vera Cruz, C.M., White, F.F., Mew, T.W. and Leung, H. (1992). Assessment of genetic diversity and population structure of Xanthomonas campestris pv. oryzae with a repetitive DNA element. Appl. Environ. Microbiol. 58 : 2188-2195.

5. Leach, J.E., White, F.F., Rhodas, M.L. and Leung, H. (1990). A repetitive DNA sequence differentiates Xanthomonas campestris pv. oryzae from other pathovars of $X$. campestris. Mol. Plant-Microbe Interact. $3: 238-246$.

6. McInnes, J.L., Forster, A.C., Skingle, D.C. and Symons, R.H. (1990). Preparation and uses of photobiotin. Methods Enzymol. 184 : 588-600.

7. Mew, T.W. (1987). Current status and future prospects of research on bacterial blight of rice. Annu. Rev. Phytopathol. 25 : 359-382.

8. Nelson, R.J., Baraoidan, M.R., Vera Cruz, C.M., Yap, I.V., Leach, J.E., Mew, T.W. and Leung, H. (1994). Relationship between phylogeny and pathotype for the bacterial blight pathogen of rice. Appl. Environ. Microbiol. 60 : 3275-3283.

9. Noda, T., Horino, O. and Ohuchi, A. (1990). Variability of pathogenicity in races of Xanthomonas campestris pv. oryzae in Japan. JARQ $23: 182-189$.

10. Tsuchiya, K., Mew, T.W. and Wakimoto, S. (1982). Bacteriological and pathological characteristics of wild types and induced mutants of Xanthomonas campestris pv. oryzae. Phytopathology $72: 43-46$.

11. Tsuchiya, K., Choi, J.E., Mew, T.W. and Wakimoto, S. (1982). Serological properties of mutant strains of Xan thomonas campestris pv. oryzae induced by $N$-methyl$N^{\prime}$-nitro- $N$-nitrosoguanidine. Ann. Phytopathol. Soc. Jpn. $48: 9-18$.

12. Wilson, K. (1990). Preparation of genomic DNA from bacteria. In Current Protocols in Molecular Biology, John Wiley \& Sons, New York, p. 2.4.1-2.4.5.

\section{和 文 摘 要}

堀田光生・土屋健一・加来久敏・平八重一之・日比忠明：高頻 度反復配列を含むプラスミド pJEL101をプローブとした RFLPによるイネ白葉枯病菌レース突然変異株の判別

フィリピン産イネ白葉枯病菌 PXO61株(レース 1)および PXO63-6 株(レース 2) からニトロソグアニジン処理によって誘 発された各種病原性変異株について, イネ白葉枯病菌由来の高 頻度反復配列を含むプラスミドpJEL101 をプローブとして RFLP 解析を行い，親株および他レース (1～5) との比較を行っ た。その結果, 2 つの親株に由来する病原性变失変異株, 病原力 低下変異株および色素非産生変異株は，それぞれ親株と概ね相 同の RFLP パターンを示した。これに対し, PXO61 株に由来す るレース変異株 $(1 \rightarrow 2)$ の RFLP パターンは親株を含むレース 1 に属する他の菌株とは明らかに異なり，レース 2 に属する多 数のフィリピン産菌株の示すパターンとほぼ相同であった。以 上の結果から，フィリピン産イネ白葉枯病菌のレース 2 群菌の 中には, 突然変異によりレース 1 群菌から分化したものが含ま れることが推察された。また，同プローブを用いた RFLP 解析 は本細菌の野生株のみならず誘発突然変異株のレース判定にお いても適用可能であることが示唆された。

(Received April 17, 1995; Accepted June 12, 1995) 